\title{
Contents, Vol. 18, 1979
}

Founded 1897 as 'Monatsschrift filir Psychiatrie und Neurologie',

continued 1957-1967 as 'Psychiatria et Neurologia'

Founders: C. Wernicke and Th. Ziehen

Successors: K. Bonhoeffer (1912-1938), J. Klaesi (1939-1967), E. Grunthal (1953-1967)

ditor-in-Chief:

Editorial Board:

Advisory Board:

G.G. Brune, Munster

J. Droogleever Fortuyn,

H.P. Ludin, Bern

Groningen

P.O. Lundberg, Uppsala

P.O. Lundberg,
Issociate Editors:

S. Feldman, Jerusalem

E. Perret, Zurich

P. Huber, Bern

C. Rieder, Basel

A. Kreindler, Bucharest

G. Scotto-Lavizzari, Basel

U.K. Rinne, Turku

H.J. Rehmann, Essen

W. Tackmann, Basel

C. Pallis, London

P. Passouant, Montpellier

E. Satoyoshi, Tokyo

F. Seitelberger, Vienna

F. Vassella, Bern

H.-G. Mertens, Wurzburg

\section{H. vander Eecken, Ghent}


S. Karger $\bullet$ Basel $\bullet$ Miinchen $\bullet$ Paris $\bullet$ London $\bullet$ New York $\bullet$ Sydney

S. Karger AG,

P.O. Box, CH-4009 Basel (Switzerland)

Printed in Switzerland by Thiir AG Offsetdruck,

Pratteln 
No part of this publication may be translated into other languages, reproduced or utilized in any form or by any means, electronic or mechanical, including photocopying, recording, microcopying, or by any information storage and retrieval system, without permission in writing from the publisher.

\section{Contents Vol. 18, 1979}

No. 1

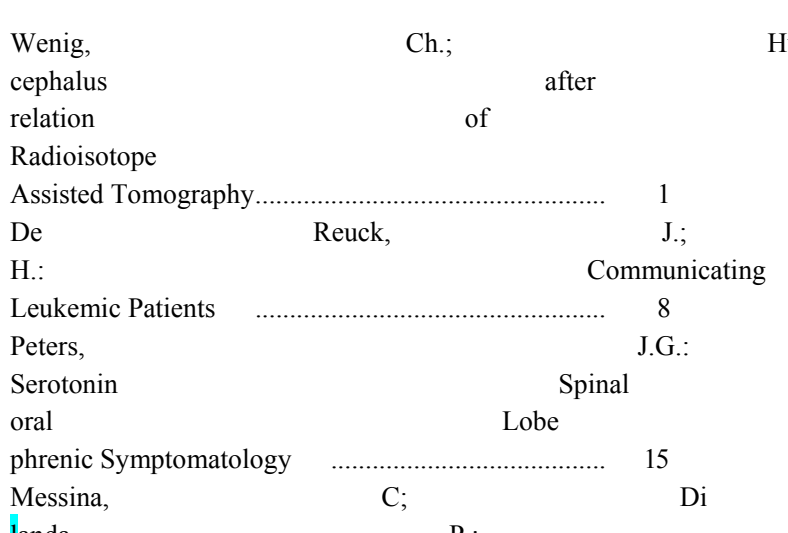

P.:

\section{No. 2}

uber,

G.,
Clinical
Cisternography

De

oster

Dopamine,

Fluid

Epileptic

Rosa,

Tonic
E.A.;
Foot:
Hydrocephalus

Findings,

$$
\text { Bleeding. }
$$

Emde,
the
and

W.

Metabolites

Patients

Dattola,
Emde,

${ }_{\text {Results }}^{\text {H.: }}$

and

in

vander

Noradrenaline

and

with

Gir-

Neuro-

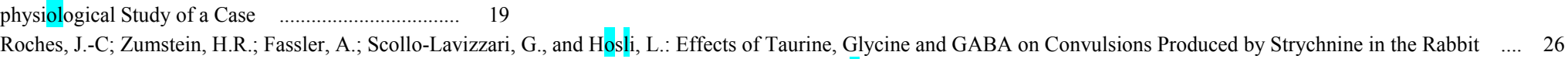

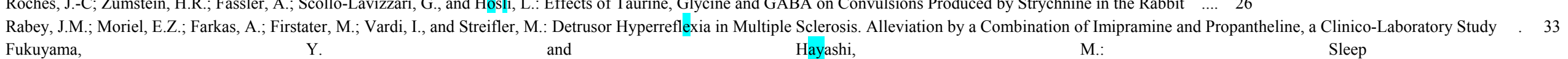
and Hayashi, M.: Sleep

encephalograms and

Stages

parathyroidism

Sleep

Нypo

Salisachs, P.; Codina, A.; Gimenez-Roldan, S., and Zarranz, J.J.: Charcot-Marie-Tooth Disease Associated with 'Essential Tremor' and Normal and/or Slightly Diminished Motor Conduction Velocity. Report of 7 Cases $\quad$... 49 Magyar, P.; Szathmary, I., and Szobor, A.: Myasthenia gravis: Lung-Function Studies without and with Edrophonium Chloride $\quad . .59$

Demeurisse,

Demol

O.,

Semiological

G.;

of

the

and

Ganty,
Palmo-Mental 66 
Bergsholm, P.; Skre, H., and M ork, S.: Creutz-

feldt-Jakob Disease. Infection of Infancy or

Childhood?

73

$\begin{array}{ll}\text { Derakhshan, } & \text { I.; } \\ \text { Subacute } & \end{array}$

H.,

and

Shafii,

A.:

munological Finding

Glands ….................................................... 79

$\begin{array}{lll}\text { Gemignani, } & \text { F.; } & \text { Neri, } \\ \text { A.; } & \end{array}$

Pietrini,

in

Saliva

and

Salivary

$\begin{array}{lll} & \text { V.; } & \text { Tagliavini, } \\ \text { Asinari, } & \text { A., } & \text { F.; }\end{array}$

Disease

of the Lower

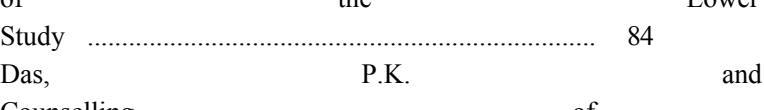

with

Familial

Savi,

Lechi,

Report

and

ymphedema

Counselling of

S.K: $\quad$ Detection

and

Voiculescu, V.; Ionescu, D.A.; Lazar, G.; Alecu, C.; Predescu, C; Popa, C; Xenakis, A.; Marcu, I., and Ghitescu, M.: Two Cases of Choreatic Syndrome Caused by Polycythemia vera ... 96
Monaco,
F.;

Pirisi, $\quad$ A

Sechi,

G.P.,

Atrophy

Optic
with

Epilepsy

ease)

Ronquist, Associated

Activity

and

and Frithz,

Cerebrospinal

Fluid

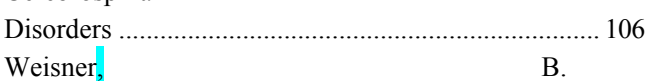

Weisner,
Therapy

mum Serum Level?

Manguiere,

F.;

Courjon,

Single

hydantoin

Manzoni,

F.; $\quad$ J.:

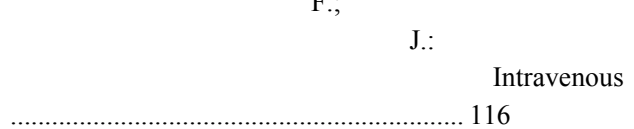

G.C.;

Interference

Epileptic

Mechanism

124

\begin{tabular}{|c|c|c|c|}
\hline \multicolumn{2}{|r|}{ and } & \multicolumn{2}{|c|}{ Bernhardt, } \\
\hline & & Whic & \\
\hline \multirow[t]{2}{*}{ Dalery, } & Transient & & $\begin{array}{l}\text { Villard, } \\
\text { Hyperkinesia }\end{array}$ \\
\hline & & Perfusion & \\
\hline \multicolumn{2}{|c|}{ Terzano, } & $\begin{array}{r}\text { M.G., } \\
\text { between }\end{array}$ & \\
\hline
\end{tabular}

G.:

(Behr's
and

and

Dis

Amino

Kinase

Neurological Different

Antiepileptic

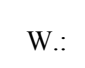

the

Opti

R.

de,

and

Diphenyl-

and

Mancia,

Intercalated

D.:

Attacks.

Varia 
Mancardi, G.L.; Primavera, A.; Leonardi, A.; De Martini, I.; Salvarani, S., and Bugiani, 0.: Tendency to Periodic Recurrence of EEG Changes in Lafora's Disease. Case Report .. 129 McDermott, J.R. and Keith, A.B.: Relative Effectiveness of Spinal Cord and Purified Myelin Basic Protein in Producing Resistance to Experimental Allergic Encephalomyelities ... 136 Fossan, G.O. $\quad$ and and $\quad$ Larsen, and
Lumbar

munoglobulin during Variation J.L.: Larsen,

$$
\text { Total }
$$

Cerebrospinal
Protein

Fluid
Im Concentra

No. 3

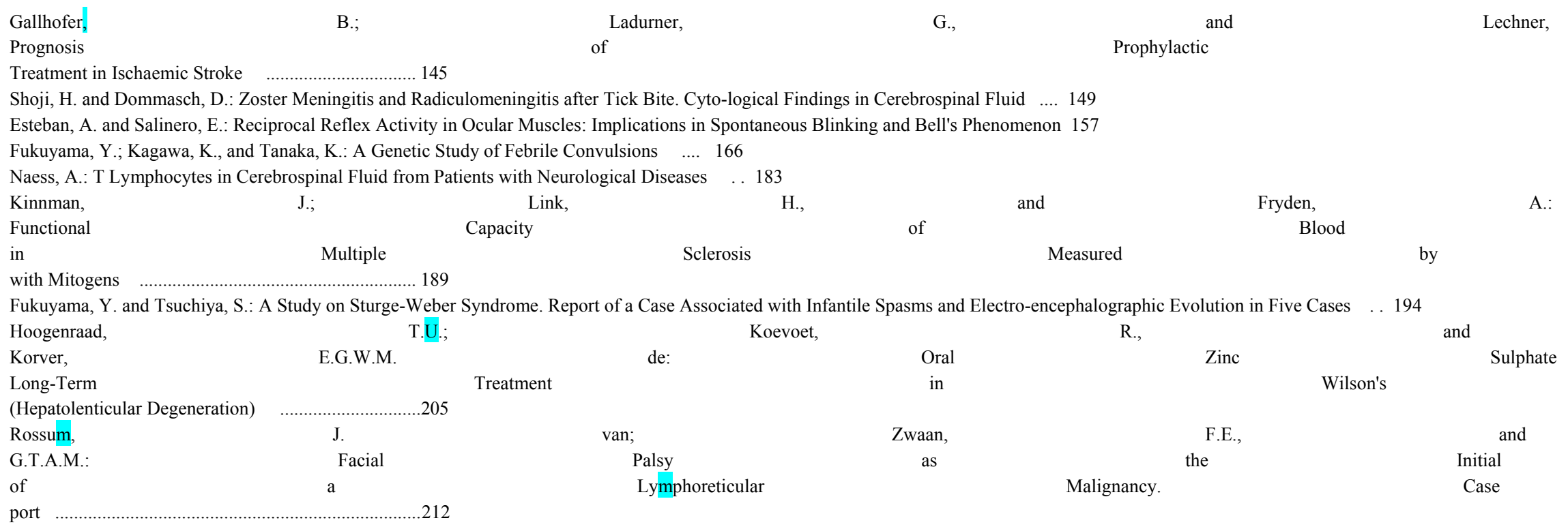

H.: Anticoagulan

Normal Lymphocytes Stimulation

Ruyter as Disease Bots, Symptom Re 
Perrone, P.; Candelise, L.; Scotti, G.; De Grandi, C, and Sciaifa, G.: CT Evaluation in Patients with Transient Ischemic Attack. Correlation between Clinical and Angiographic Findings . 217 Wasterlain, C.G.: Does Anoxemia Play a Role in the Effects of Neonatal Seizures on Brain Growth? An Experimental Study in the Rat .222
Agnetti,
V.;
Monaco,
F.,
Spinal $\quad$ Epidural
and
Mutani,
Haematoma

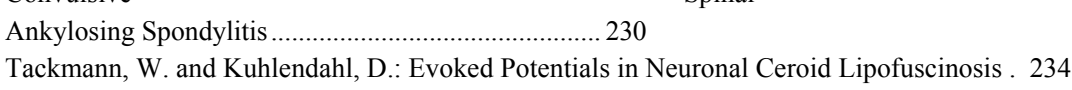

R.:

Post-

Tackmann, W.; Strenge, H.; Barth, R., and Sojka-Raytscheff, A.: Diagnostic Validity for Different Components of Pattern Shift Visual Evoked Potentials in Multiple Sclerosis .... 243

Leinonen, H.; Juntunen, J.; Somer, H., and Rapola, J.: Capillary Circulation and Morphology in Duchenne Muscular Dystrophy . 249

Egloff-Baer,

and$$
\text { Roth, }
$$

Egloff-Baer,

G.:

Ephaptic

Recurrent

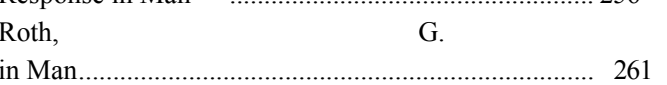

A., Szulc-Kuberska, J., and

Macchi,

ssini,

Conditions and Neuroactive Drugs.............................269

...280

Book Reviews

\section{No. 5}

Ladurner, G.; Sager, W.D.; Iliff, L.D., and Lechner, H.: A Correlation of Clinical Findings and CT in Ischaemic Cerebrovascular Disease . 281

Brezis,

stein,

O.

and

Analy
S.:

Ephaptic

and

267

Therapy in

Caltagirone,

C;

Jakob-Creutzfeldt

and

Evoked

EEG

Ghanem,

J.;

D.:

Weiler-Ravell,

David,

Potentials

Disease:

P.,

under

Basal

Morris, Acute

Quadriplegic

Intermitten
D.;

and

Coma sponse 289
Ep
Pro

Porphyria.

and pranolol

Respiratory Failure Contents 
Depresseux, J.C.; Rousseau, J.J., and Franck, G.: The Autoregulation of Cerebral Blood Flow, the Cerebrovascular Reactivity and Their Interaction in the Shy-Drager Syndrome .... 295
Fukuyama,
Y.;
Shionaga,
and
Iida,
Whole Night
Sleep

$\mathrm{Y}$ :

Poly-
in

graphic $\quad$ Study

Bourre, J.M.; Haltia, M.; Daudu, O.; Monge, M., and Baumann, N.: Infantile Form of So-Called Neuronal Ceroid Lipofuscinosis: Lipid Biochemical Studies, Fatty Acid Analysis of Cerebroside Sulfatides and Sphingomyelin, Myelin Density Profile and Lipid Composition 312

Fossan, G.O. and Aarli, J.A.: Immunoglobulin G in Serum and Cerebrospinal Fluid from Epileptic Patients Treated with Phenytoin .. 322

and Johanson, C.E.:

of Cerebrospinal Fluid in Uremia $\quad$............................. $328 \quad$ Melamed, $\quad$ E.,

Argov,

parathyroidism Presenting

rological Features
Zaccara,

E.,

The

Sink

Action

and Galli,

A.:

S.:

fied $\quad$ Dosage

Schedules

$\mathrm{A}$

.

Effectiveness

Unusual

Hyper

Neu

Simpli

the Management

Cuypers, J.; $\quad$ Altenkirch,

H.,

py

of

Ciganek,

L.

Cluster $\quad$ Headache

and

Bunge,

S.:

Automated

Diagnosis

and Gliviak,

Syndromic

Lesions

Nerves 348

of

with

Histamine

Thera

Siegfried, J. and Haas, H.L.: Inhibition by Transcutaneous Electrical Stimulation of Noxious Heat Elicited in Human Gasserian Ganglion . 353
Kito
S.
Yamamoto,
M.;
Itoga,
in

D.: Cyclic

Nucleotides
F.:

the

E.,
Computerized Topographical
Kishida, Muscular 
No. 6

Ophthalmople

I.;

Lotfi,

J.,

(Fisher's $\quad$ Syndrome). Ataxia $\quad$ With

Demonstrated by CT Scanning Sy......... 361

Vanholder,

R.;

De

With

Reuck,

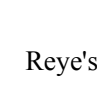

$\mathrm{J}$

Syndrome

Sieben-Praet,

Adult

Coster,

, D.F.,Carasso, R., and Streifler, M.: Painful Ophthalmoplegia: the Tolosa-Hunt Syndrome 373

Yoshii, Y.; Maki,

Y

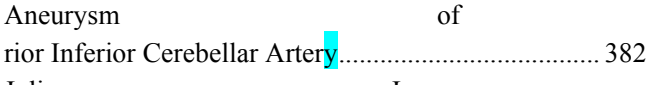

Julien, J.; $\quad$ Vital,

……........................ 387

Chang, $\quad$ B.

and

Y.,

(n)

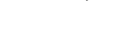

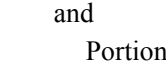

Egashira,

Portion

Vallat,

Agitated

J.M.,

Delirium

and Morariu,

ic'Locked-in| Syndrome
Stoica, E. and Enulescu, O.: Un.................................391

in Cerebral Infarct Patients. 395

Glotzner, F.L.; Planner, $\quad$ M., $\quad$ and

atine

Kinase

Planner,

and

P.;

Wessely,

Rathkolb,

.

of

.. .405

Investigations

;

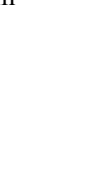

M.A.:

after $\quad$ Gaab, $\quad$ Grand

H.D.;

Kogelnik,

O.:

Misonidazole
Lesion

M.,

Giant

Poste

Bourgoin,

and

Caused

Traumat

Cre
mal

Muller,

Electroneurographic Polyneuro

Bautista, J.; Gil-Neciga, E., and Gil-Peralta, A.: Hypokalemic Periodic Paralysis in Primary Hyperaldosteronism. Subclinical Myopathy with Atrophy of the Type 2A Muscle Fibers . 415

Book Review

. .421

Author Index

...422

Subject Index 